\title{
Late Paleozoic or early Mesozoic magnetizations in remagnetized Paleozoic rocks, State of Oaxaca, Mexico
}

\author{
Chad McCabe ${ }^{1}$, Rob Van der Voo ${ }^{2}$ and Jaime Urrutia-Fucugauchi ${ }^{3}$ \\ 1 Department of Geology and Geophysics, Louisiana State University, Baton Rouge, LA 70803 (U.S.A.) \\ 2 Department of Geological Sciences, University of Michigan, Ann Arbor, MI 48109-1063 (U.S.A.) \\ ${ }^{3}$ Instituto de Geofisica, Universidad Nacional Autónoma de México, Delegacion Coyoacan 04510 D.F., México (Mexico)
}

Received June 6, 1988; revised version received September 12, 1988

\begin{abstract}
Characteristics of the Oaxaca Terrane of southern Mexico suggest that the record of a complete Wilson cycle is present. The local basement is composed of high-grade rocks of the Oaxaca Complex, which is considered to have North American affinities based on Grenvillian lithologies and ages. In contrast, early Paleozoic sedimentary rocks in depositional contact with the Oaxaca Complex have very close faunal affinities with the Olenid-Ceratopygid trilobite province of Argentina. Late Paleozoic faunas indicate that by this time the Oaxaca Terrane was once again associated with North America. In an attempt to gain further insight into the drift history of this area, we have undertaken a paleomagnetic study of the Paleozoic sedimentary rocks of Oaxaca.

The results of our study indicate that the entire Paleozoic section was remagnetized in the same paleomagnetic field at some time following late Paleozoic sedimentation, emplacement of an igneous complex, and the earlier of two folding events. Fold and conglomerate tests show that the remagnetization occurred prior to deposition and folding of overlying early Cretaceous sediments. The Oaxaca Paleozoic rocks were therefore remagnetized sometime between late Permian and early Cretaceous. Since the exact age of remagnetization is not known, we compare our result with data from cratonic North America for the bracketed range of magnetization ages. This analysis indicates that as much as $28^{\circ}$ of net counterclockwise rotation could have occurred between Oaxaca and cratonic North America subsequent to the Oaxaca remagnetization.
\end{abstract}

\section{Introduction}

Southern Mexico is made up of a number of distinct basement terranes. These terranes are "suspect" in that they differ in lithology, structural style, fossil assemblages, metamorphic grade, and radiometric basement age. One of these is the Oaxaca Terrane. The Oaxaca Metamorphic Complex forms the basement to this terrane, and is exposed in the central part of the State of Oaxaca. On the basis of lithologies present, the granulite facies metamorphic grade, and radiometric ages in the range of $900-1100 \mathrm{Ma}$, the Oaxaca Complex has been considered to have formed as a part of the Grenville Province of North America [1,2]. Paleomagnetic study of Oaxaca Complex rocks has revealed the presence of a steep component of magnetization $(D / I=6 /+74)[3]$. This magnetization is consistent with those reported from the Grenville Province of eastern Canada provided that the Oaxaca Terrane is now displaced, and originally formed near the Grenville rocks presently exposed in the Ontario-Quebec area [3]. Field observations also support the idea that the Oaxaca Terrane is displaced. Where exposed, the perimeter of the Oaxaca Complex is bounded by wide mylonitic zones, and the adjacent terranes have basement ages that are Paleozoic or younger [2].

Though the Oaxaca basement appears to have North American affinities, overlying early Paleozoic sedimentary rocks have clearly non-North American faunas. Tremadocian rocks contain an abundant trilobite fauna that has close affinities with the Olenid-Ceratopygid province [4,5]. This province is now dispersed, and may be found today in England and Wales, eastern Newfoundland, South America, and other areas outside of cratonic North America [5]. The Oaxaca faunas are most closely similar to those found in Argentina [5].

The geological evidence thus indicates that the Oaxaca Terrane may have undergone a complete 
Wilson cycle, and that paleomagnetic studies might be helpful in providing additional details of its drift history. With this goal in mind, we have undertaken a paleomagnetic study of both early and late Paleozoic sedimentary rocks from the State of Oaxaca.

\section{Geology and sampling}

The Paleozoic rocks of the Oaxaca Terrane crop out in two small exposures in the Nochixtlán region of Oaxaca State (Fig. 1). First described in 1967 [4], these sediments rest with depositional contact on the Grenville-aged rocks of the Oaxaca Metamorphic Complex $[2,4,6]$. Both early and late Paleozoic rocks are present in the canyon of Santiago-Ixtaltepec, the larger of the two localities, where west dipping beds are exposed for about $7 \mathrm{~km}$ along strike (Fig. 1). A Lower Cretaceous conglomerate lies above the Paleozoic with pronounced angular discordance. The Cretaceous rocks are only gently folded, and form a broad anticlinal structure in this area. Thin, sparsely distributed rhyodacitic dikes and sills that predate Cretaceous sedimentation have intruded the Paleozoic rocks.

The second exposure is the Tiñu type section locality (Fig. 1) which is very small, measuring only about $200-500 \mathrm{~m}$. Only the early Paleozoic part of the section is preserved at this locality. The

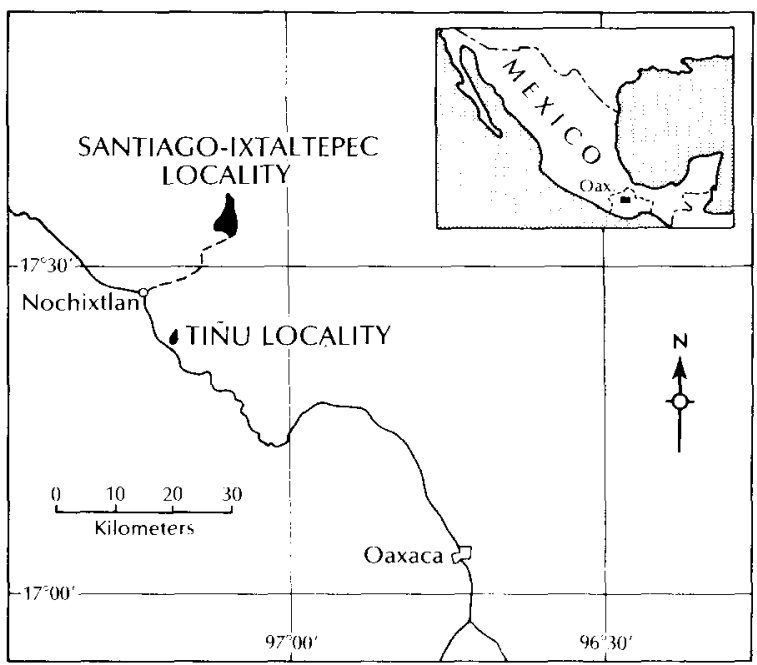

Fig. 1. Map of the Nochixtlan area of the State of Oaxaca showing the locations of the two sampling localities.

\begin{tabular}{|c|c|}
\hline CRETACEOUS & CONGLOMERATE \\
\hline JURASSIC & \multirow{2}{*}{$\begin{array}{l}\text { INTRUSION } \\
\text { EARLIER FOLOINO }\end{array}$} \\
\hline TRIASSIC & \\
\hline PERMIAN & YODODFÑE FM \\
\hline PENNSYLVANIAN & IXTALTEPEC FM. \\
\hline MISSISSIPPIAN & \multirow[t]{4}{*}{ SANTIAGO FM. } \\
\hline DEVONIAN & \\
\hline SILURIAN & \\
\hline \multirow[t]{2}{*}{ ORDOVICIAN } & \\
\hline & \multirow[t]{2}{*}{ TIÑU FM. } \\
\hline CAMBRIAN & \\
\hline
\end{tabular}

Fig. 2. Stratigraphic section of the Paleozoic sedimentary rocks of the Oaxaca Terrane.

rocks here have northeasterly dips, and are overlain by flatlying Tertiary clastic sediments.

A schematic stratigraphy of the Paleozoic section is shown in Fig. 2. The Lower Paleozoic part of the section occurs as limestones and fine-grained clastics of the Tremadocian (Cambro-Ordovician) Tiñu Formation. The Tiñu is highly fossiliferous, and contains trilobites of the Olenid-Ceratopygid province. At the Santiago-Ixtaltepec locality, Upper Paleozoic sedimentary rocks overlie the Tiñu with very slight angular discordance. The Mississippian is represented by fossiliferous limestones and shales of the Santiago Formation. The Pennsylvanian Ixtaltepec Formation, composed primarily of clastic rocks, lies above the Santiago. Unfossiliferous clastics of the Yododeñe Formation form the top of the Paleozoic section. The Yododeñe has been assigned a late Pennsylvanian to middle Permian age based on its stratigraphic and tectonic setting [6].

The Paleozoic rocks have been deformed at least twice, once following deposition but prior to the early Cretaceous, and once after deposition of early Cretaceous conglomerates and finer-grained clastics. This two-stage deformation has important implications for our paleomagnetic analysis since the tectonic corrections can be applied in two 
increments for two fold tests. An additional field test on the age of the magnetization is a conglomerate test on Upper Paleozoic clasts within the Lower Cretaceous conglomerate. As will be shown later, a final constraint on the age of the magnetizations depends on the age of the rhyodacitic intrusives that cut the Yododeñe Formation but predate Lower Cretaceous sedimentation. Unfortunately, no radiometric ages exist for these intrusive bodies. Their age therefore is constrained only as post Yododeñe (middle Permian?) and pre-early Cretaceous.

For a paleomagnetic study, we sampled: (1) limestones of the Tremadocian Tiñu Formation at both the Santiago-Ixtaltepec locality, and at the Tiñu type section locality; (2) limestones of the Mississippian Santiago Formation at the canyon of Santiago-Ixtaltepec; (3) red sandstones of the Pennsylvanian Ixtaltepec Formation at SantiagoIxtaltepec; (4) the intrusive rocks; and (5) clasts of Paleozoic sandstones within the Lower Cretaceous conglomerate. Additional paleomagnetic data from a site in the Pennsylvanian-Permian Yododeñe Formation were provided for this analysis by W.A. Gose [7].

Samples were collected in the field both as oriented hand samples, and as cores taken with a gasoline-powered field drill. Samples were oriented with a magnetic compass and clinometer. Standard 2.54 by $2.2 \mathrm{~cm}$ specimens were prepared for the laboratory analyses.

\section{Laboratory studies}

Specimens were demagnetized in stepwise fashion using both alternating field (AF) and thermal techniques in the paleomagnetic laboratory at the University of Michigan. Measurements were made on a two-axis ScT cryogenic magnetometer. After initial study, it was determined that thermal demagnetization produced the best results, and most of the specimens were treated using this method.

Demagnetization data were plotted on orthogonal demagnetization plots [8], and directions of the characteristic magnetizations were determined using principal component analysis [9] when possible. Some of the limestone specimens appeared to reach a stable endpoint after about $300^{\circ} \mathrm{C}$, but the magnetization became unstable after treatment at higher temperatures. For these samples, a stable endpoint direction was determined following inspection of demagnetization diagrams.

\section{Results}

Two distinct kinds of rock magnetic characteristics were observed in the demagnetization data. The Santiago and Tiñu Limestone magnetizations were readily broken down by AF demagnetization, and had blocking temperature ranges that did not exceed about $500^{\circ} \mathrm{C}$. In contrast, the Ixtaltepec, conglomerate clast, and igneous dike magnetizations could not be removed by AF demagnetization to $100 \mathrm{mT}$, and had maximum blocking temperatures up to $680^{\circ} \mathrm{C}$. This difference in behavior suggests that the main carrier of magnetization in the igneous and sandstone samples is hematite, and that the limestone magnetization is carried in magnetite.

Despite this difference in rock magnetic characteristics, all of the units sampled appear to have been magnetized in the same paleomagnetic field. Thermal demagnetization diagrams depicted in Fig. 3 show behavior that is representative for the Tiñu, Santiago, Ixtaltepec, and dike samples. After removal of a soft, probably viscous magnetization, a characteristic magnetization is revealed that is directed to the southeast and moderately down. All specimens demagnetized have the same, apparently reversed, polarity.

As mentioned previously, the field relationships indicate that at least two folding events have affected the Paleozoic rocks, one following Paleozoic deposition but prior to the early Cretaceous, and one following Cretaceous sedimentation. At the Santiago-Ixtaltepec locality, the geometry of the post-early Cretaceous folding can be determined from the attitude of the overlying Cretaceous rocks, and the magnetization directions of the Paleozoic rocks can therefore be corrected for this younger folding event. The poles to bedding of the Paleozoic strata can also be rotated according to the attitude of the overlying Cretaceous rocks in order to yield rotation parameters for a total, or two-stage tilt correction. Directions from the intrusive rocks were corrected in the same two-increment manner using the attitude of the intruded beds to correct the magnetization directions. This procedure assumes only that the intrusives and country rock were magnetized at about 

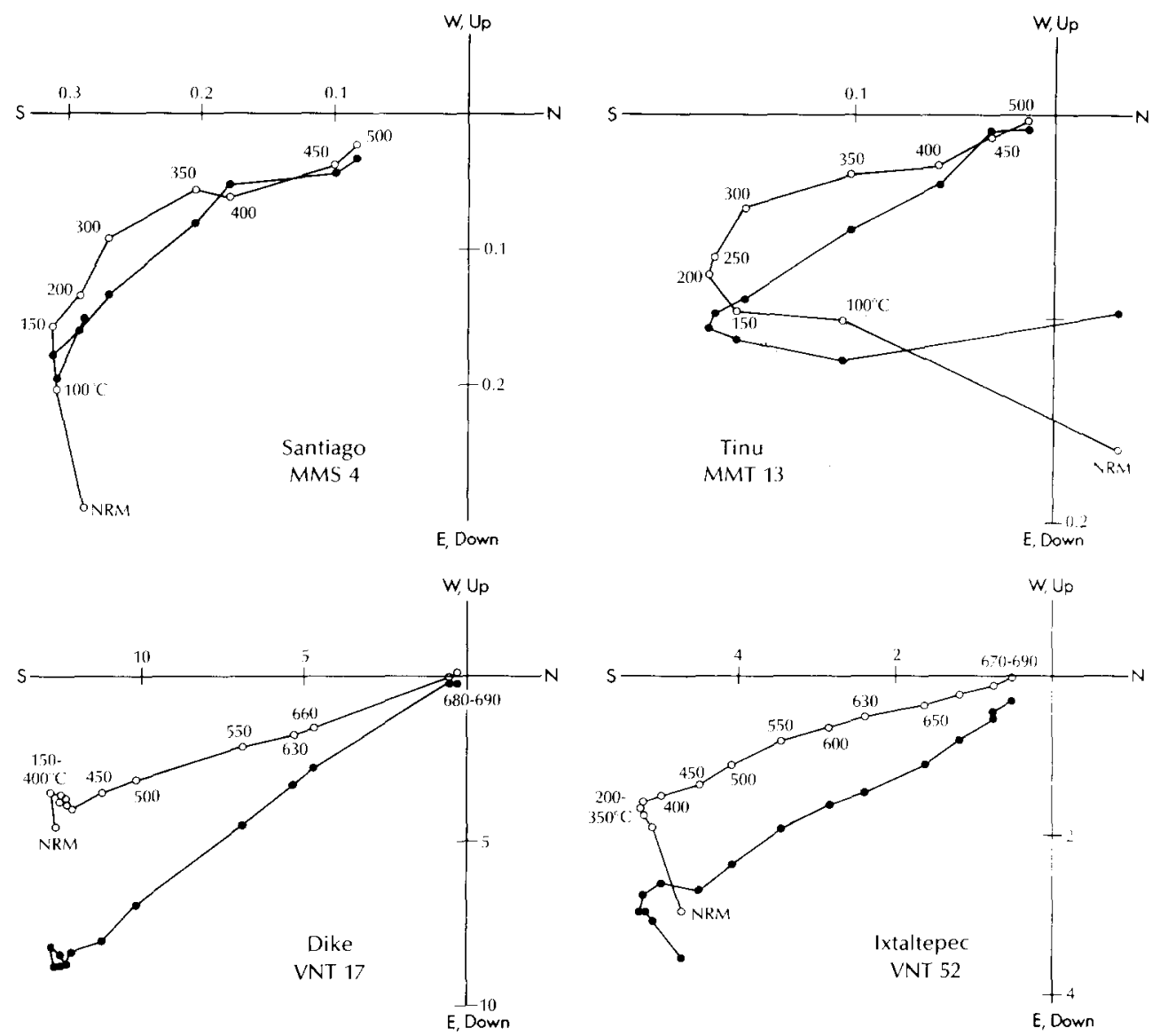

Fig. 3. Representative demagnetization diagrams [8] of the four sampled rock units as indicated. Open circles are the projections of the magnetization vector endpoints onto a north-south vertical plane; solid circles are the projections onto the horizontal plane. Magnetization units are milliamps per meter.

the same time. The validity of this assumption will be examined in more detail later. Since the sedimentary rocks overlying the Paleozoic at the Tinu type section locality are flatlying, this sort of analysis cannot be performed there. For purposes of the two-increment fold test, it was assumed that rocks at this locality were not deformed in postearly Cretaceous time.

Site mean directions are listed in Table 1 and plotted in Fig. 4. Directions are shown with no tectonic correction, after correction for post-early Cretaceous folding, and after a two-stage tectonic correction is applied. The worst clustering of directions is produced by the two-stage tectonic correction (Fig. 4c). Because the Cretaceous rocks occur in gently-dipping beds, the difference between the distribution of directions corrected for post-early Cretaceous folding (Fig. 4b) and no correction (Fig. 4a) is small and not statistically significant. However, a slightly better clustering of directions occurs after correction for the younger folding event. On the other hand, clustering of the site poles is significantly better $(p=0.95)$ after correction for the younger folding compared with the two-stage unfolding [11]. The data thus indicate that remagnetization occurred after the earlier folding but probably before the later folding.

A further constraint on the upper bracket of the magnetization age is provided by the results of a conglomerate test on clasts of Paleozoic rocks within the early Cretaceous conglomerate. The sandstone clasts sampled were similar in lithology to the Yododeñe and Ixtaltepec sandstones, and were probably derived from those units. The attitude of bedding within each clast was recorded, but it could not be determined whether the clasts 


\section{TABLE 1}

Summary of paleomagnetic data by site and means of all sites. $N / N_{0}$ is the number of specimen directions used in the calculation of the site mean compared to the number of specimens demagnetized. $K, k, \alpha_{95}$ and $A_{95}$ are statistical parameters [10]. See text for explanation of the two tectonic corrections (T.C.'s) used

\begin{tabular}{|c|c|c|c|c|c|c|}
\hline Site & $N / N_{0}$ & $k$ & $\alpha_{95}$ & $\begin{array}{l}\text { In situ } \\
D / I\end{array}$ & $\begin{array}{l}\text { Post-Cretaceous T.C. } \\
D / I\end{array}$ & $\begin{array}{l}\text { Two-stage T.C. } \\
D / I\end{array}$ \\
\hline \multicolumn{7}{|c|}{ Intrusive rocks } \\
\hline 47 & $4 / 4$ & 45.5 & 13.8 & $153.0 / 14.7$ & $154.9 / 16.6$ & $175.6 / 27.4$ \\
\hline 48 & $5 / 5$ & 35.4 & 13.0 & $164.8 / 35.1$ & $169.8 / 35.4$ & $183.9 / 34.4$ \\
\hline \multicolumn{7}{|c|}{$Y_{\text {ododeñe }}^{a}$} \\
\hline & $23 / 26$ & 48.3 & 4.4 & $150.8 / 15.9$ & $152.8 / 18.1$ & $152.9 / 23.1$ \\
\hline \multicolumn{7}{|c|}{ Ixtaltepec } \\
\hline 50 & $5 / 5$ & 30.1 & 14.2 & $152.1 / 14.1$ & $153.9 / 16.1$ & $172.7 / 24.8$ \\
\hline 51 & $2 / 2$ & 893.2 & & $155.8 / 16.5$ & $157.9 / 18.1$ & $169.9 / 23.7$ \\
\hline 52 & $3 / 4$ & 222.1 & 8.3 & $154.2 / 9.8$ & $155.5 / 11.6$ & $162.8 / 21.9$ \\
\hline 53 & $5 / 5$ & 79.4 & 8.6 & $148.2 / 25.9$ & $151.6 / 28.3$ & $170.0 / 38.1$ \\
\hline \multicolumn{7}{|c|}{ Santiago } \\
\hline 1 & $4 / 4$ & 156.5 & 7.4 & $155.0 / 14.0$ & $159.3 / 28.4$ & $172.6 / 31.3$ \\
\hline 2 & $5 / 5$ & 38.6 & 12.5 & $148.8 / 9.7$ & $151.7 / 25.3$ & $163.9 / 31.4$ \\
\hline 3 & $4 / 6$ & 19.1 & 21.6 & $149.9 / 41.2$ & $161.5 / 42.2$ & $182.2 / 38.8$ \\
\hline 4 & $5 / 6$ & 51.5 & 10.8 & $157.7 / 25.0$ & $163.8 / 24.8$ & $174.5 / 22.6$ \\
\hline 5 & $5 / 5$ & 42.5 & 11.9 & $148.2 / 29.0$ & $155.6 / 30.8$ & $170.3 / 31.3$ \\
\hline 6 & $2 / 2$ & 78.1 & & $163.5 / 8.0$ & $166.8 / 20.8$ & $172.2 / 19.1$ \\
\hline 7 & $5 / 6$ & 474.9 & 3.5 & $151.8 / 6.8$ & $153.5 / 8.5$ & $157.9 / 12.0$ \\
\hline \multicolumn{7}{|c|}{$\operatorname{Tiñu}$} \\
\hline 1 & $6 / 12$ & 23.3 & 14.2 & $155.2 / 23.8$ & $155.2 / 23.8$ & $131.3 / 28.3$ \\
\hline 2 & $10 / 11$ & 42.5 & 7.5 & $155.4 / 21.5$ & $155.4 / 21.5$ & $133.7 / 27.8$ \\
\hline 3 & $5 / 5$ & 42.7 & 11.8 & $145.2 / 8.4$ & $147.4 / 11.5$ & $151.4 / 24.8$ \\
\hline 4 & $7 / 7$ & 27.2 & 11.8 & $130.0 / 14.9$ & $133.7 / 21.1$ & $144.6 / 31.4$ \\
\hline 5 & $4 / 5$ & 26.0 & 18.4 & $133.7 / 10.2$ & $136.4 / 15.7$ & $144.8 / 25.4$ \\
\hline \multirow{2}{*}{\multicolumn{4}{|c|}{ Means of site mean $D / I$ 's: }} & $151.1 / 18.3$ & $154.3 / 22.2$ & $162.4 / 28.0$ \\
\hline & & & & $k=42.0 ; \alpha_{95}=5.2$ & $k=48.0 ; \alpha_{95}=4.9$ & $k=29.3 ; \alpha_{95}=6.3$ \\
\hline \multirow{2}{*}{\multicolumn{4}{|c|}{ Means of site poles: }} & $50.7^{\circ} \mathrm{N} ; 131.4^{\circ} \mathrm{E}$ & $51.3^{\circ} \mathrm{N} ; 125.3^{\circ} \mathrm{E}$ & $53.1^{\circ} \mathrm{N} ; 111.7^{\circ} \mathrm{E}$ \\
\hline & & & & $K=66.3 ; A_{95}=4.2$ & $K=67.0 ; A_{95}=4.1$ & $K=28.1 ; A_{95}=6.4$ \\
\hline
\end{tabular}

Data from the Yododeñe Fm. provided for this analysis by W.A. Gose. Data were originally reported in [7].

were upright or overturned. Clast magnetizations were very stable during stepwise thermal demagnetization, as can be seen in Fig. 5b. As a consistency test, two samples were taken from one of the clasts, and the characteristic directions were found to be concordant. Fig. 5a shows clast mean directions from the conglomerate clasts (with respect to clast bedding). Note that declinations are dispersed, but that the inclinations have moderate values, either up or down. The mean (absolute value) inclination with respect to clast bedding is relatively constant, and consistent with inclina- tions found in the in-place Paleozoic rocks (mean $I=14^{\circ} \pm 9^{\circ}$ ). However, the in situ clast inclinations are much more dispersed (mean $I=31^{\circ} \pm$ $20^{\circ}$ ). The conglomerate test is clearly positive, indicating that the magnetization was acquired before deposition of the early Cretaceous conglomerate. This result indicates that correction of the magnetization directions for the younger folding is required, despite the statistically weak fold test on that folding stage. The mean direction after this correction is applied is $D / I=154.3 / 22.2$ $\left(k=48.0 ; \quad \alpha_{95}=4.9^{\circ}\right)$. The paleomagnetic pole 


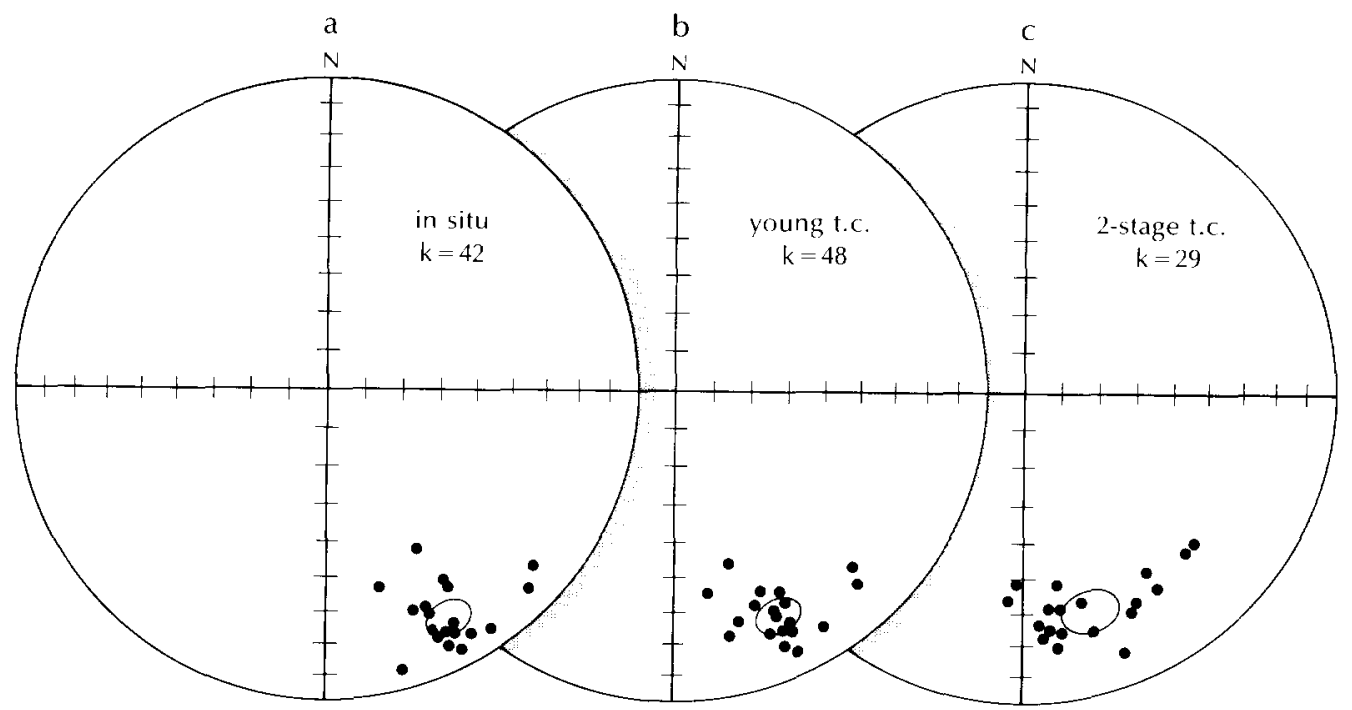

Fig. 4. (a) Site mean characteristic directions from the Tiñu, Santiago, Ixtaltepec, Yododeñe, and igneous rocks without any tectonic correction. Circle of $95 \%$ confidence about the mean direction is shown. Mean direction itself is omitted for clarity. Equal area projection. (b) As in preceding diagram, but with a correction applied for the younger (post-early Cretaceous) folding event. (c) As in preceding diagrams but with directions corrected in two stages for the two folding events.

calculated from site poles is located at $51.3^{\circ} \mathrm{N}$ latitude, and $125.3^{\circ} \mathrm{E}$ longitude $\left(K=67.0 ; A_{95}=\right.$ $4 \cdot 1^{\circ}$ ).

\section{Discussion}

The excellent agreement of site directions and polarities is a clear indication that all the units sampled were remagnetized at about the same time. This remagnetization has prevented us from fulfilling the original objective of this study, which was to constrain the Paleozoic drift history of the Oaxaca Terrane. However, since the age of the remagnetization is reasonably well determined, the results of this study are not without significance.

The remagnetization age is constrained by the age of the rocks sampled, by the two-stage fold test, and by the conglomerate test. The observed remagnetization must be younger than the intrusives, which are the youngest rocks sampled, and also younger than the older folding. Unfortunately, the ages of the earlier folding and intrusive events are not yet well constrained: they are strictly bracketed only as post-Yododeñe (middle Permian?) and pre-early Cretaceous. A firm upper bracket for the remagnetization age is provided by the conglomerate test, which demonstrates that the magnetization is older than the early Creta- ceous conglomerate. Strict age brackets for the remagnetization are therefore post-Yododeñe (middle Permian?) and pre-early Cretaceous. However, since the magnetization is younger than two post-Yododeñe events, folding and intrusion, some time must have elapsed between the cessation of Yododeñe sedimentation and the remagnetization event. We therefore consider late Permian to be a reasonable estimate of the lower bracket of the magnetization age. This estimate will no doubt require revision when radiometric ages become available for the intrusive igneous rocks.

The paleomagnetic pole we obtained is plotted in Fig. 6 along with reference poles from cratonic North America [12]. The excellent agreement of our mean Oaxaca remagnetization pole with late Paleozoic (Kiaman Interval) paleomagnetic results from cratonic North America [12] would seem to indicate that the Oaxaca sedimentary rocks were remagnetized during the late Paleozoic. However, paleomagnetic data from post-Paleozoic rocks from other parts of Mexico reveal a complicated and as yet poorly understood history of tectonic rotations (real or apparent) and latitudinal displacements of the various Mexican terranes with respect to cratonic North America [13]. It is paradoxical that the Oaxaca pole we have obtained is in such good agreement with late Paleo- 
zoic poles from the craton, when younger Mexican rocks that lie closer to cratonic North America yield highly anomalous results [13]. These considerations indicate that a late Paleozoic remagnetization cannot be tacitly assumed on the basis of the pole position: the agreement of the Oaxaca mean pole with late Paleozoic North American

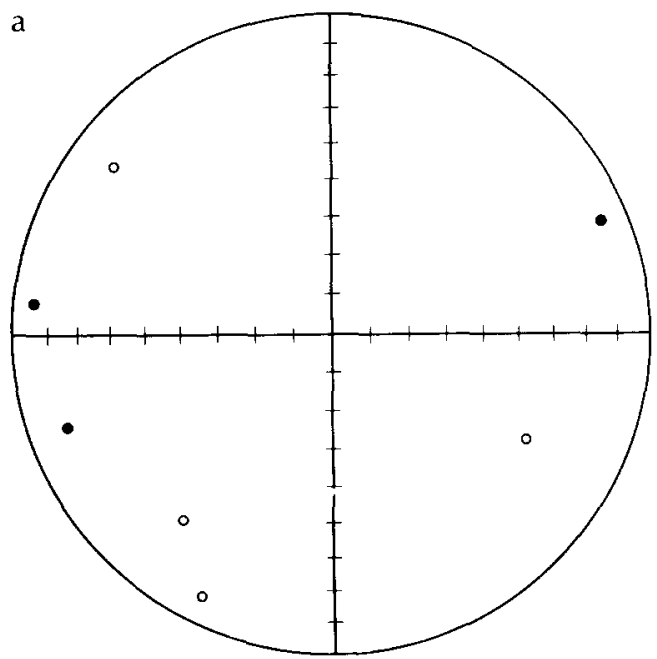

b

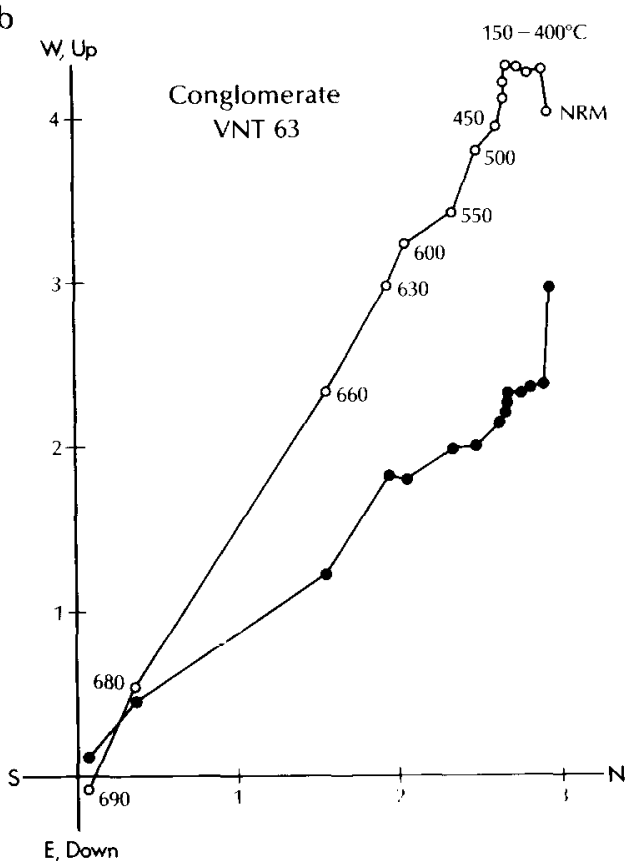

Fig. 5. Results of the conglomerate test. (a) Clast mean directions (with respect to within-clast bedding) in equal area projection. (b) Representative demagnetization diagram (in situ coordinates) for a conglomerate clast specimen. Conventions and units are the same as in Fig. 3.

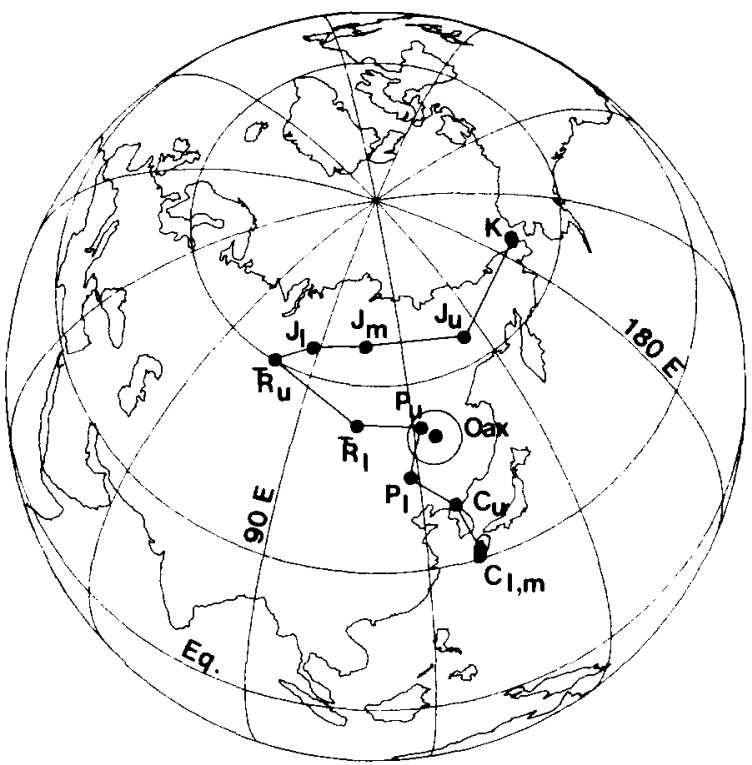

Fig. 6. Oaxaca remagnetization mean pole (after correction for post-early Cretaceous folding) surrounded by its $A_{95}$. Paleomagnetic poles from cratonic North America are shown for reference, and were calculated from data given in [12] with a quality factor of 5 or greater.

ones might be coincidental, and the result of a younger remagnetization age combined with tectonic displacements.

It is of interest therefore to evaluate the result of the present study in light of possible deviations with data from cratonic North America over the bracketed age of the magnetization. This has been done graphically in Fig. 7. Fig. 7A shows that there is no discernible flattening (a parameter that indicates latitudinal displacement $[14,15]$ ) of the Oaxaca remagnetization direction with respect to those expected for North America if remagnetization is late Permian to early Jurassic in age. The figure shows also that if the remagnetization occurred in the later Jurassic, the Oaxaca Terrane must have been far to the south of North America. We consider this situation unlikely because available Cretaceous and Triassic-Jurassic paleomagnetic data from Oaxaca show no indication of such a latitudinal displacement ([13] for review). If this line of reasoning is valid, then the remagneti. zation event can be no younger than approximately early Jurassic.

Fig. 7B shows the rotation $[14,15]$ of the Oaxaca remagnetization direction with respect to direc- 

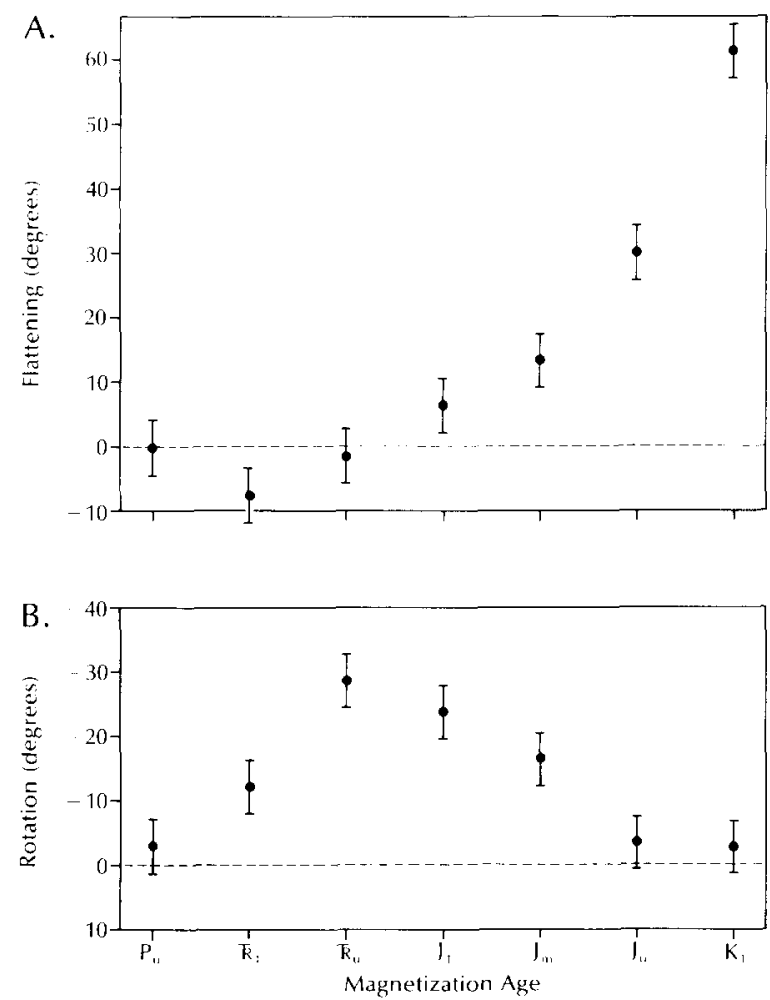

Fig. 7. (A) Flattening and (B) rotation [14] with error bars [15] of the Oaxaca mean direction with respect to cratonic North America plotted against possible remagnetization ages. Expected directions for this analysis calculated from data given in [12] with a quality factor of 5 or greater.

tions expected for cratonic North America for the site over the bracketed remagnetization age range. The results of this analysis indicate no rotation with respect to the craton for the late Permian, but counterclockwise rotations of up to $28^{\circ}$ for the early Mesozoic (Fig. 7B). Our results also appear to indicate post-Paleozoic relative tectonic motions between Oaxaca and nearby terranes in southern Mexico. Approximately coeval magnetizations from the Paleozoic Acatlán Terrane [16], which lies immediately to the northwest of the Oaxaca block, have south-southwesterly declinations indicating clearly clockwise rotations of the Acatlán block with respect to cratonic North America. The mean Oaxaca magnetization direction is therefore rotated counterclockwise with respect to the adjacent Acatlán terrane.

\section{Conclusions}

The Paleozoic sedimentary rocks of Oaxaca State were completely remagnetized sometime be- tween approximately late Permian and early Jurassic. Our results indicate that by late Paleozoic or early Mesozoic time, the Oaxaca Terrane could have been in about the same latitudinal position with respect to cratonic North America that it occupies today. However, it is possible that since that time there has been a small net relative rotation of the Oaxaca Terrane with respect to the craton. Depending on the exact age of the remagnetization described in this paper, this net rotation could be as little as nil to as much as $28^{\circ}$ in a counterclockwise sense. Counterclockwise rotation of Oaxaca with respect to the adjacent Acatlán Terrane is more clearly established, indicating some post-Paleozoic tectonic mobility between the blocks that comprise southern Mexico. The plate tectonic context of this rotation is not as yet fully apparent, but our data will be useful in evaluating the results of future geologic and paleomagnetic studies from southern Mexico.

\section{Acknowledgements}

We thank W.A. Gose for providing us with the details of his paleomagnetic data from the Yododeñe Formation. This work was supported by the National Science Foundation, grant EAR 8313085.

\section{References}

1 C. Fries Jr., E. Schmitter-Villada, P.E. Damon and D.E. Livingston, Rocas Precámbricas de edad Grenvilliana de la parte central de Oaxaca en el sur de México, Bol. Inst. Geol. Univ. Nac. Autónoma de México 64, 45-53, 1962.

2 F. Ortega-Gutierrez, Metamorphic belts of southern Mexico and their tectonic significance, Geof. Intern. 20, 177-202, 1981.

3 M.M. Ballard, R. Van der Voo and J. Urrutia-Fucugauchi, Paleomagnetic results from Grenville-aged rocks from Oaxaca, Mexico: evidence for a displaced terrane, Precambrian Res. (in press).

4 J. Pantoja-Alor and R.A. Robison, Paleozoic sedimentary rocks in Oaxaca, Mexico, Science 157, 1033-1035, 1967.

5 H.B. Whittington and C.P. Hughes, Geography and faunal provinces in the Tremadoc Epoch, in: Paleogeographic provinces and provinciality, C.A. Ross, ed., Soc. Econ. Paleontol. Mineral., Spec. Publ. 21, 203-218, 1974.

7 J. Pantoja-Alor, Rocas sedimentarias paleozoicas de la region centro-septentrional de Oaxaca, Soc. Geol. Mex., Libro-Guía de la Excursión México-Oaxaca, pp. 67-84, 1970. 
7 W.A. Gose and L.A. Sanchez-Barreda, Paleomagnetic results from southern Mexico, Geof. Intern. 20, 163-176, 1981.

8 J.D.A. Zijderveld, A.C. demagnetization of rocks: analysis of results, in: Methods in Paleomagnetism, D.W. Collinson and S.K. Runcorn, eds., pp. 245-286, Elsevier, Amsterdam, 1967.

9 J.L. Kirschvink, The least-squares line and plane and analysis of paleomagnetic data, Geophys. J.R. Astron. Soc. 45, 699-718, 1980.

10 R.A. Fisher, Dispersion on a sphere, Proc. R. Soc. London, Ser. A 217, 295-305, 1953.

11 M.W. McElhinny, Statistical significance of the fold test in paleomagnetism, Geophys. J.R. Astron. Soc. 8, 338-340, 1964.

12 R. Van der Voo, Paleomagnetism of Continental North America: the craton, its margins, and the Appalachian belt, in: Geophysical Framework of the Continents, L.C. Pakiser and W.D. Mooney, eds., Geol. Soc. Am., Mem. (in press).

$13 \mathrm{~J}$. Urrutia-Fucugauchi, On the tectonic evolution of Mexico: paleomagnetic constraints, in: Plate Reconstructions from Paleozoic Paleomagnetism, R. Van der Voo, C.R. Scotese and N. Bonhommet, eds., Am. Geophys. Union, Geodyn. Ser. 12, 29-47, 1984.

14 M.E. Beck, Jr., Paleomagnetic record of plate-margin tectonic processes along the western edge of North America, J. Geophys. Res. 85, 7115-7131, 1980.

15 H.H. Demarest, Jr., Error analysis for the determination of tectonic rotation from paleomagnetic data, J. Geophys. Res. 88, 4321-4328, 1983.

16 Fang Wu, R. Van der Voo and J. Urrutia-Fucugauchi, Paleomagnetism of the Acatlán complex, southern Mexico, EOS 67, 267, 1986. 